\title{
Dynamic analysis of sugar metabolism in different harvest seasons of pineapple (Ananas comosus L. (Merr.))
}

\author{
X.M. Zhang, M.A. Dou , Y.L. Yao , L.Q. Du , J.G. Li and G.M. Sun* \\ South Subtropical Crop Research Institute,Chinese Academy of Tropical Agricultural Science , Zhanjiang, Guangdong \\ 524091, China and College of Horticultur, South China Agricultural University, Guangzhou 510642, China.
}

Accepted 18 November, 2010

\begin{abstract}
In pineapple fruits, sugar accumulation plays an important role in flavor characteristics, which varies according to the stage of fruit development. Metabolic changes in the contents of fructose, sucrose and glucose and reducing sugar related to the activities of soluble acid invertase (Al), neutral invertase (NI), sucrose synathase (SS) and sucrose-phosphate synthase (SPS) were studied in winter and summer pineapple fruits in this paper. Sucrose was significantly increased in most of the harvesting winter fruits which reached the peak of $64.87 \mathrm{mg} \cdot \mathrm{g}-1 \mathrm{FW}$ at 130 days after anthesis, while hexose was mainly accumulated at the 90 day of the summer fruits in July. The ratio of hexose to sucrose was 5.92:0.73 from the winter fruit in February. Interestingly, the activities of SPS and SS synthetic direction of the harvested fruits in February were significantly higher than those in July, whereas the invertase activities were exactly opposite. NI activity showed a similar trend to Al, but the amount of NI activity was higher than Al in both months. Therefore, NI appears to be one of the vital enzymes in pineapple fruit development. Conclusively, the enzyme activities related to sugar play key roles in the eating of quality pineapple, which could be improved by cultivation in different seasons. So we can arbitrate different temperature to improve the quality of pineapple fruits according to market demand.
\end{abstract}

Key words: Pineapple (Ananas comosus), different harvest seasons, sucrose, sucrose phosphate synthase, sucrose synthase.

\section{INTRODUCTION}

Fruit taste and quality depends on such factors as sugars, organic acids, firmness, amino acids and aromatic compounds. Sugars synthesized in source tissues are one of the most important sugars, which are transported into sink tissues such as fruit, shoots and other tissues (Itai and Tanahashi, 2008). Sucrose serves an integral role as both a source of carbon and energy for non-photosynthetic tissues, which is central to plant metabolism and the most

*Corresponding author. E-mail: gm-sun@163.com. Tel: +86759-2859205. Fax: +86-759- 2859124.

Abbreviations: SPS, Sucrose phosphate synthase; SS, sucrose synthase; Al, acid invertase; SAl, soluble acid invertase; NI, neutral invertase; TSS, total soluble solid; TA, titratable acid; HPLC, high performance liquid chromatograph; BSA, bovine serum albumin; PVP, polyvinylpyrrolidone; EDTA, ethylenediaminetetraacetic acid. dominant metabolite involved in the growth and development of fruit (Park et al., 2009).

However, primary sucrose metabolism is governed by several enzymes like sucrose phosphate synthase (SPS), sucrose synthase (SS) and acid invertase (Al) (Yamaki and Moriguchi, 1989; Moriguchi et al., 1992; Tanase and Yamaki, 2000). SPS has been suggested to be the key enzyme responsible for sucrose accumulation in pineapple fruit (Chen and Paull, 1998; Nilprapruck et al., 2008). Al such as soluble acid invertase (SAI) and neutral invertase (NI) can cleave sucrose to glucose and fructose (Davies and Robinson, 1996). SS can either cleave sucrose to UDP-glucose and fructose or catalyze the reverse, synthetic reaction in the control of sucrose import and fruit growth parameters (D'Aoust et al., 1999).

The composition of sucrose, glucose and fructose plays a key role in determining the sweetness in tomato (Bruyn, 1971), papaya (Gomez et al., 2002), peach (Colaric et al., 2004), apple (Róth et al., 2007; Veberic et al., 2007), and 
pineapple fruits (Bartolomé et al., 1996; Kermasha et al., 1987; Shinjro et al., 2004). According to some reports, there are considerable differences in sucrose content and commercially important cultivars such as 'Red Spanish', 'Smooth Cayenne' and 'Kew' (Bartolomé et al., 1996; Kermasha et al., 1987). Chen and Paull, (1998) reported that glucose and fructose were the predominant sugars during early fruit development. Sucrose began to accumulate 6 weeks before harvest at a higher rate in the interfruitlet tissue. Nilprapruck et al. (2008) found that total sugars and reducing sugars of pineapple treated by methyl jasmonate (MeJA) on chilling injuries were not significantly different from that of the control pineapple. Liu et al. (2009) reported that the flavor in summer pineapple fruit was better than that of the winter fruit. Joomwong (2006) showed that the fruit harvested in winter had the highest content of total soluble solid (TSS) and titratable acid (TA), and the lowest ratio of TSS : TA than any other seasons. However, the correlation between development and sugar metabolism in the 'smooth cayenne' cultivated in the different harvest seasons is yet unknown.

This study aims to gain a better insight into the relation between the different harvesting seasons and sugar accumulation, the enzymes related to sucrose metabolism, effect of different harvest seasons on the sugar accumulation and its physiology during pineapple fruit development.

\section{MATERIALS AND METHODS}

\section{Plant and fruit material}

Field-grown pineapples [Ananas comosus L. (Merr.) cv. smooth cayenne] were cultivated in the pineapple resource bank of South Subtropical Crops Research Institute. Winter and summer fruits were collected during the fruit development seasons, from November 2005 to February 2006 and from May 2007 to July 2007, respectively.

The experimental design used in this study was under the same management conditions such as irrigation, fertilization, soil management, disease control and pruning. One hundred and fifty fruit samples in each season had been selected after the full florescence period. The fruits were randomly sampled every 10 days from the 20th day after anthesis, and cut transversely into 3 sections after the size and weight of crowns and fruits were measured. Only the flesh of the middle section was used for the determination of the sugar content and sucrose synthase activity in this study. These sliced fleshes of 30 fruits were pooled together as one of five replications at each harvesting time. After collection, the tissues were immediately frozen in liquid nitrogen and stored at $-80^{\circ} \mathrm{C}$ before being analyzed.

\section{Determinations of fructose, glucose and sucrose content}

Soluble sugars, sucrose, glucose and fructose were determined by high performance liquid chromatograph (HPLC) as previously described by N'tchobo et al. (1999) with slight modifications. Approximately, $1 \mathrm{~g}$ frozen fruit fresh tissue was homogenized with 5 $\mathrm{ml}$ deionized water, incubated at $80^{\circ} \mathrm{C}$ in a water bath for $15 \mathrm{~min}$, and centrifuged at $15000 \mathrm{~g}$ for $15 \mathrm{~min}$. The pellet fraction was redissolved with $4 \mathrm{ml}$ sterile water and recentrifuged at $15000 \mathrm{~g}$ for 15 min, combining the two clear supernatant and adding sterile water to make it $10 \mathrm{ml}$. Individual sugars were quantified by injecting a $10 \mu \mathrm{l}$ aliquot of sample into a HPLC (PE Corp., America) equipped with an analysis column (Series200, $250 \times 4.6 \mathrm{~nm}, 5 \mu \mathrm{m}$ ), a differential refractometer (PE200) and a reporting integrator. The mobile phase was degassed $\mathrm{CH} 3 \mathrm{CN}: \mathrm{H} 2 \mathrm{O}=70: 30(\mathrm{~V} / \mathrm{V})$, at a flow rate of $1.0 \mathrm{ml} \cdot \mathrm{min}^{-1}$ and $35^{\circ} \mathrm{C}$. Peak height measurements were used to quantify the soluble sugars by comparing them to peak height of a standard solution.

\section{The analysis of invertase (Ivr), SPS and SS activity}

Extractions of enzymes were prepared essentially in frozen flesh tissues as described by Miron and Schaffer (1991) and Eduardo et al., (2001). Fruit material was homogenised in $10 \mathrm{ml}$ of ice-cold homogenising buffer containing $50 \mathrm{mmol} \cdot \mathrm{L}^{-1}$ Hepes- $\mathrm{NaOH}(\mathrm{pH} 7.5)$, $0.5 \mathrm{mmol} \cdot \mathrm{L}^{-1} \mathrm{Na}$ - ethylenediaminetetraacetic acid (EDTA), 2.5 $\mathrm{mmol} \cdot \mathrm{L}^{-1} \mathrm{DTT}, 3 \mathrm{mmol} \cdot \mathrm{L}^{-1}$ diethyldithiocarbamic acid, $0.5 \%(\mathrm{~W} / \mathrm{V})$ bovine serum albumin (BSA) and $1 \%(\mathrm{~W} / \mathrm{V})$ insoluble polyvinylpyrrolidone (PVP). After centrifugation at $12000 \mathrm{~g}$ for $20 \mathrm{~min}$ at $4{ }^{\circ} \mathrm{C}$, supernatants were dialyzed for approximately $20 \mathrm{~h}$ against 25 $\mathrm{mmol} \cdot \mathrm{L}^{-1}$ Hepes-NaOH $(\mathrm{pH} 7.5)$ and $0.25 \mathrm{mmol} \cdot \mathrm{L}^{-1} \mathrm{Na}-\mathrm{EDTA}$ and used as the crude soluble enzyme extract. The insoluble pellet was washed twice in homogenising medium and then incubated with shaking for $4 \mathrm{~h}$ in ice-cold homogenising medium containing 1 $\mathrm{mol} \cdot \mathrm{L}^{-1} \mathrm{NaCl}$.

Invertase activities were measured as described by Qi et al. (2007). The soluble and insoluble acid and neutral invertases activities were assayed in a final volume of $25 \mathrm{ml}$, containing $0.2 \mathrm{ml}$ of dialyzed enzymatic extraction, $0.8 \mathrm{ml}$ of reaction solution $(\mathrm{pH} 4.8$ or $7.2,0.1 \mathrm{~mol} \cdot \mathrm{L}^{-1} \mathrm{Na}_{2} \mathrm{HPO} 4,0.1 \mathrm{~mol} \cdot \mathrm{L}^{-1}$ sodium citrate, $0.1 \mathrm{~mol} \cdot \mathrm{L}^{-1}$ sucrose for acid invertase and neutral invertase, respectively). The activities were measured by the quantity of reducing sugars released in the assay media with dinitrosalicylic acid.

Activity of SPS was assayed according to the method of Miron and Schaffer (1991) using $0.15 \mathrm{ml}$ of reaction medium and $0.2 \mathrm{ml}$ of enzyme sample. The reaction medium is composed of $50 \mathrm{mmol} \cdot \mathrm{L}^{-1}$ Mops- $\mathrm{NaOH}(\mathrm{pH} 7.5), 10 \mathrm{mM} \mathrm{MgCl}, 5 \mathrm{mmol} \cdot \mathrm{L}^{-1}$ glucose-6phosphate, $10 \mathrm{mmol} \cdot \mathrm{L}^{-1}$ fructose- 6 -phosphate and $5 \mathrm{mmol} \cdot \mathrm{L}^{-1}$ uridine diphosphate glucose (UDPG). The mixture was incubated for $30 \mathrm{~min}$ at $37^{\circ} \mathrm{C}$ and the reaction was stopped by adding $0.1 \mathrm{ml}$ $30 \%(\mathrm{w} / \mathrm{v}) \mathrm{NaOH}$ and kept in boiling water for $5 \mathrm{~min}$. When cooled to room temperature, the resorcinol solution $(12 \%, \mathrm{v} / \mathrm{v})$ of $0.5 \mathrm{ml}$ and $\mathrm{HCl}\left(12 \mathrm{~mol} \cdot \mathrm{L}^{-1}\right)$ of $0.5 \mathrm{ml}$ were added into the mixture and held in an $80^{\circ} \mathrm{C}$ water bath for 10 min. Blank controls were obtained by adding the sterile water to the reaction medium containing resorcinol. The procedure for the sucrose synthase assay was identical to that of SPS except the reaction mixtures that contained $10 \mathrm{~mm}$ fructose and did not contain fructose 6- phosphate or glucose 6phosphate.

\section{Statistical analysis}

All data were analyzed using different software, DPSv3.01 for the variance analysis and the correlation analysis by SAS9.0 according to different requirements was done. The relationship between sugars and enzyme activities were described with linear correlation analysis.

\section{RESULTS}

The effect of different harvesting seasons on the fruit development dynamics

Pineapple fruits growth measured as changes in weight 


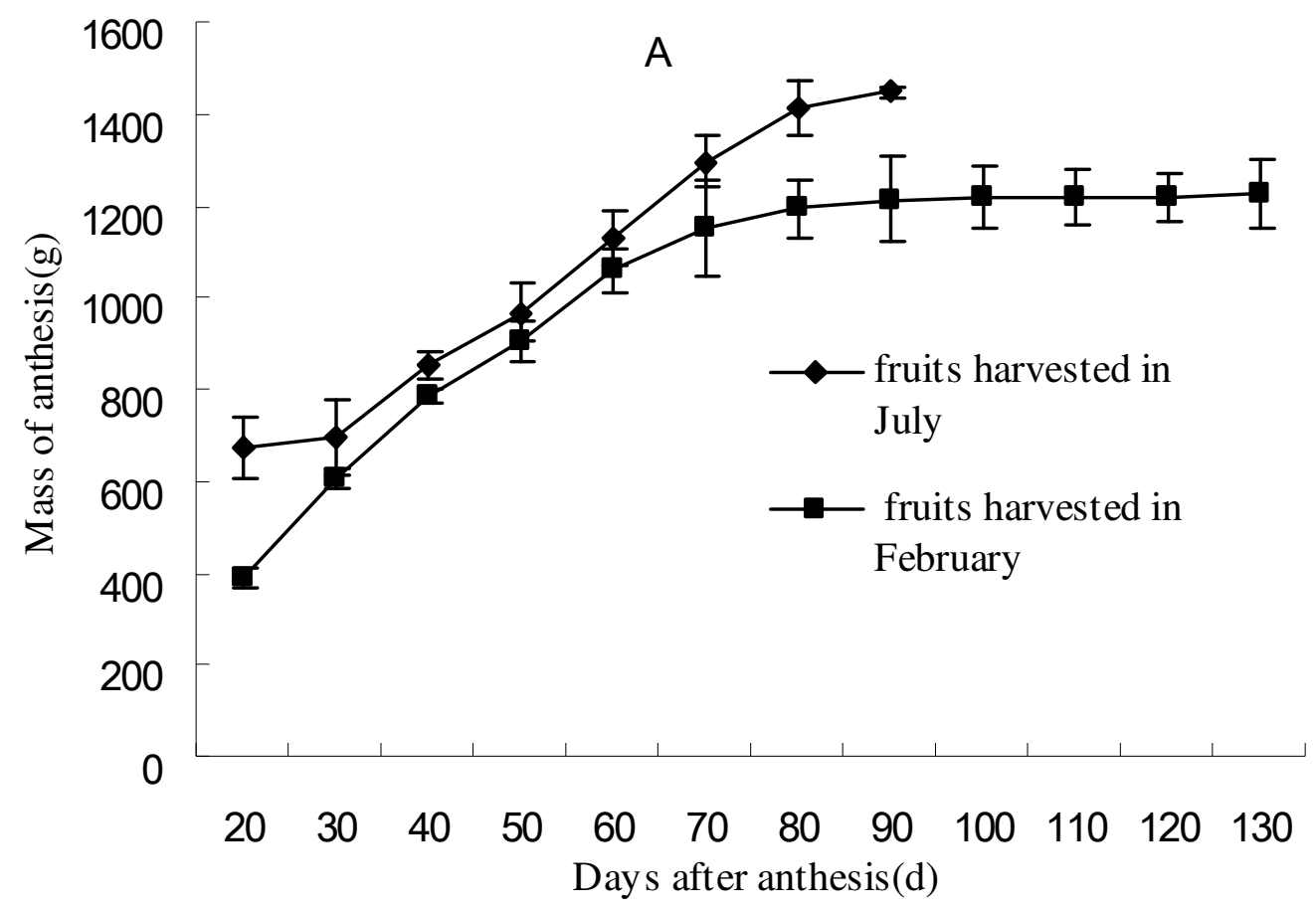

Figure 1. Effects of different harvest seasons on fruit developments of 'smooth cayenne 'pineapple.

showed that the development of the summer fruits was a typical S curve (slow - fast - slow), but the winter's was not a typical $S$ curve (fast - slow) (Figure 1) in different seasons. During the 30 to 80 days, the summer fruits increased rapidly, then remained stable. However, the fast growth period of winter fruits were from the 20 to 90 days, then its variance was also small $(2.13 \%)$ at the mature period.

The development of the winter fruits (harvested in February) were 40 days longer than that of the summer fruit (harvested in July), but its weight was opposite.

\section{The changes of fruit sugar content in the different harvesting seasons}

As the fruit developed, the sucrose content was increased firstly, and then declined in the whole development in the summer fruits (Figure 2A). The sucrose content was low during the former 40 days (lower than $5.63 \mathrm{mg} \cdot \mathrm{g}^{-1} \mathrm{FW}$ ), then accumulated slightly, reached the peak at the 70 days $\left(20.95 \mathrm{mg} \cdot \mathrm{g}^{-1} \mathrm{FW}\right)$, dropped at the maturity (16.67 $\left.\mathrm{mg} \cdot \mathrm{g}^{-1} \mathrm{FW}\right)$ at the end. Compared with sucrose content, the ratio of hexose (fructose and glucose) to sucrose was 5.92. The hexose was the predominant sugar and gradually increased with the highest level presented at ripe stage. Hexoses accumulated to higher lever in 90 days after anthesis. The content vales were 54.68 and $43.89 \mathrm{mg} \cdot \mathrm{g}^{-1} \mathrm{FW}$, respectively. The changes of glucose and fructose were basically consistent. It suggested that the summer fruits mainly accumu- lated hexose, and the total sugar content was 115.23 $\mathrm{mg} \cdot \mathrm{g}^{-1} \mathrm{FW}$.

In the early stage of development of the winter fruits, the fructose content accumulated rapidly from 5.03 to $15.50 \mathrm{mg} \cdot \mathrm{g}^{-1} \mathrm{FW}$ during 20 to 50 days, and gradually increased to the peak in the 130 days $\left(24.31 \mathrm{mg} \cdot \mathrm{g}^{-1} \mathrm{FW}\right)$ (Figure 2B). The glucose content significantly improved from 3.71 to $22.09 \mathrm{mg} \cdot \mathrm{g}^{-1} \mathrm{FW}$ at the beginning of 60 days, then reached the maximum. At this period, glucose accumulation was in agreement with fructose accumulation. The accumulations of glucose and fructose were fluctuant till the harvest. However, the content of sucrose slightly increased during the young fruits and reached the peak $\left(64.87 \mathrm{mg} \cdot \mathrm{g}^{-1} \mathrm{FW}\right)$ at the ripe fruits, which was the $60.54 \%$ of total sugar. During this process, the main sugar accumulation was sucrose, and the content of total sugar was $107.16 \mathrm{mg} \cdot \mathrm{g}^{-1} \mathrm{FW}$.

\section{The SPS activity in different seasons}

The changes in SPS activity of pineapple fruit, harvested at different development stages and different ripening conditions, are shown in Figure 3. In the winter and summer fruits, peak times and values of SPS activity were obviously different, though their tendencies all increased. In the winter fruits, the SPS activity was not detected in the beginning of 30 days, sharply improved from the 90 to 100 days. Peak activity with the maximum value of $67.90 \mu \mathrm{mo} 1 \cdot \mathrm{h}^{-1} \mathrm{~g}^{-1} \mathrm{FW}$ appeared in the 120 days after anthesis, and then dropped off at the harvest. In 

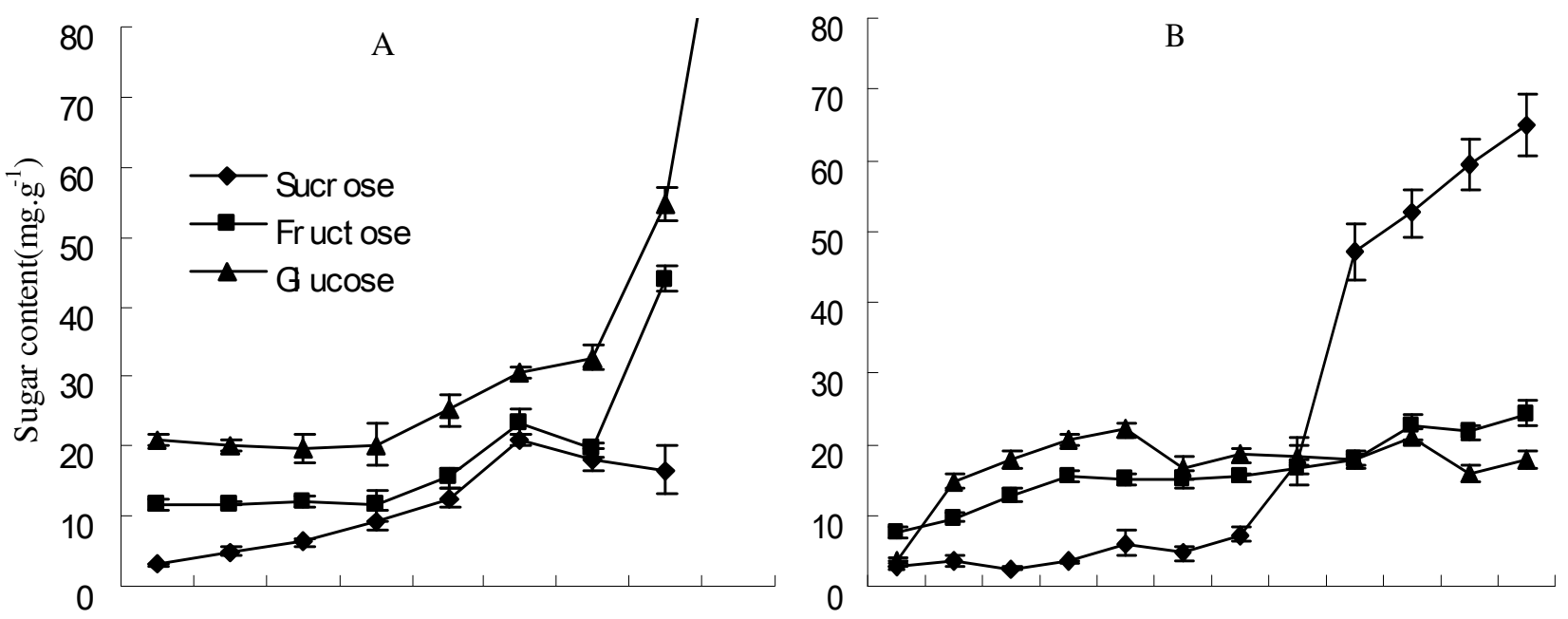

$\begin{array}{llllllll}20 & 30 & 40 & 50 & 60 & 70 & 80 & 90\end{array}$

$20 \quad 30 \quad 40 \quad 50 \quad 60 \quad 70 \quad 80 \quad 90 \quad 100110120130$

Days after anthesis (d)

Figure 2. Effects of different harvest seasons on sugar contents in the developing pineapple fruits. A: Fruits harvested in July; B: Fruits harvested in February.

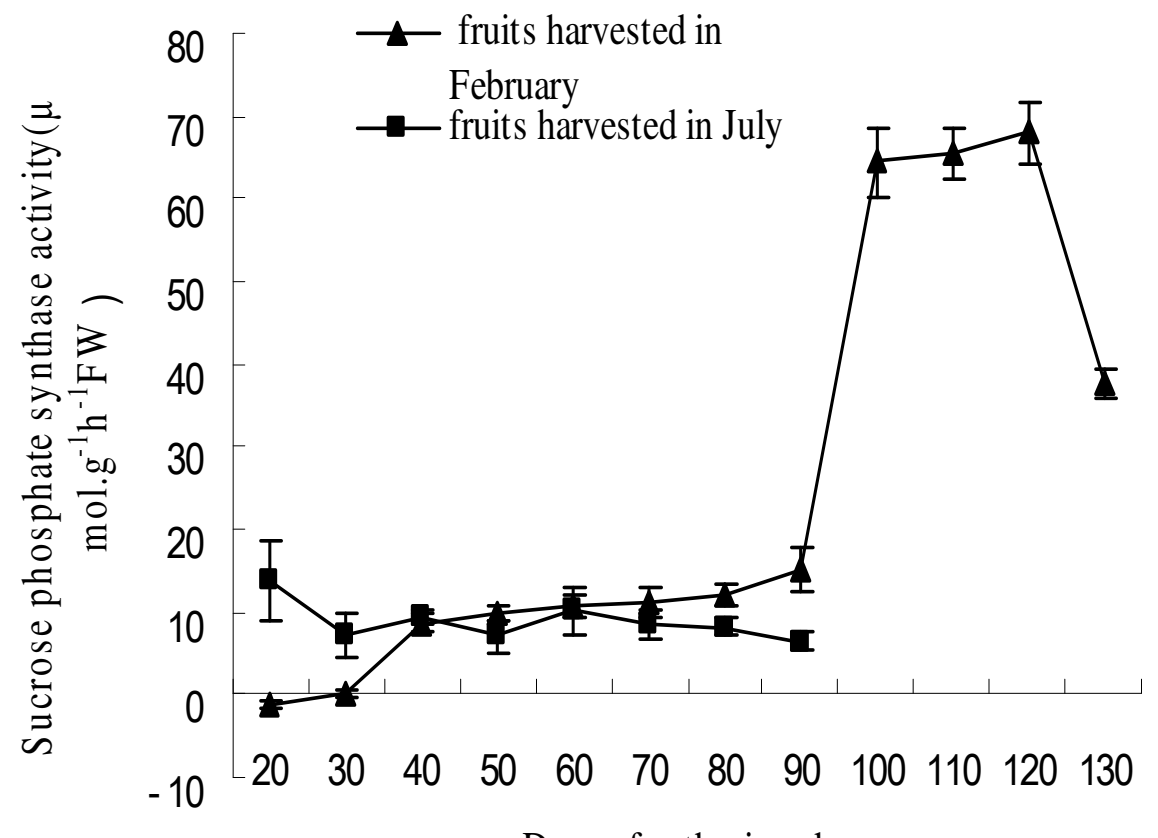

Days of anthesis $(\mathrm{d})$

Figure 3. Effects of different harvest seasons on SPS activities in the developing pineapple fruits.

contrast, no significant difference could be observed in the activity of SPS in the summer fruits with the exception of the assessment of the 40th day. It started to go up to the maximum of $13.79 \mu \mathrm{mo} 1 \cdot \mathrm{h}^{-1} \mathrm{~g}^{-1} \mathrm{FW}$, and similarly, was down to the lowest level at maturity. The total activity in winter ripened fruits was 5.83 times than in the summer.

\section{The SS activity in different seasons}

SS activities that can act both in synthesizing and cleaving sucrose were measured in the winter and summer fruits. In young fruits, the activity of synthesis direction of SS showed low activity that was more stable and lower 


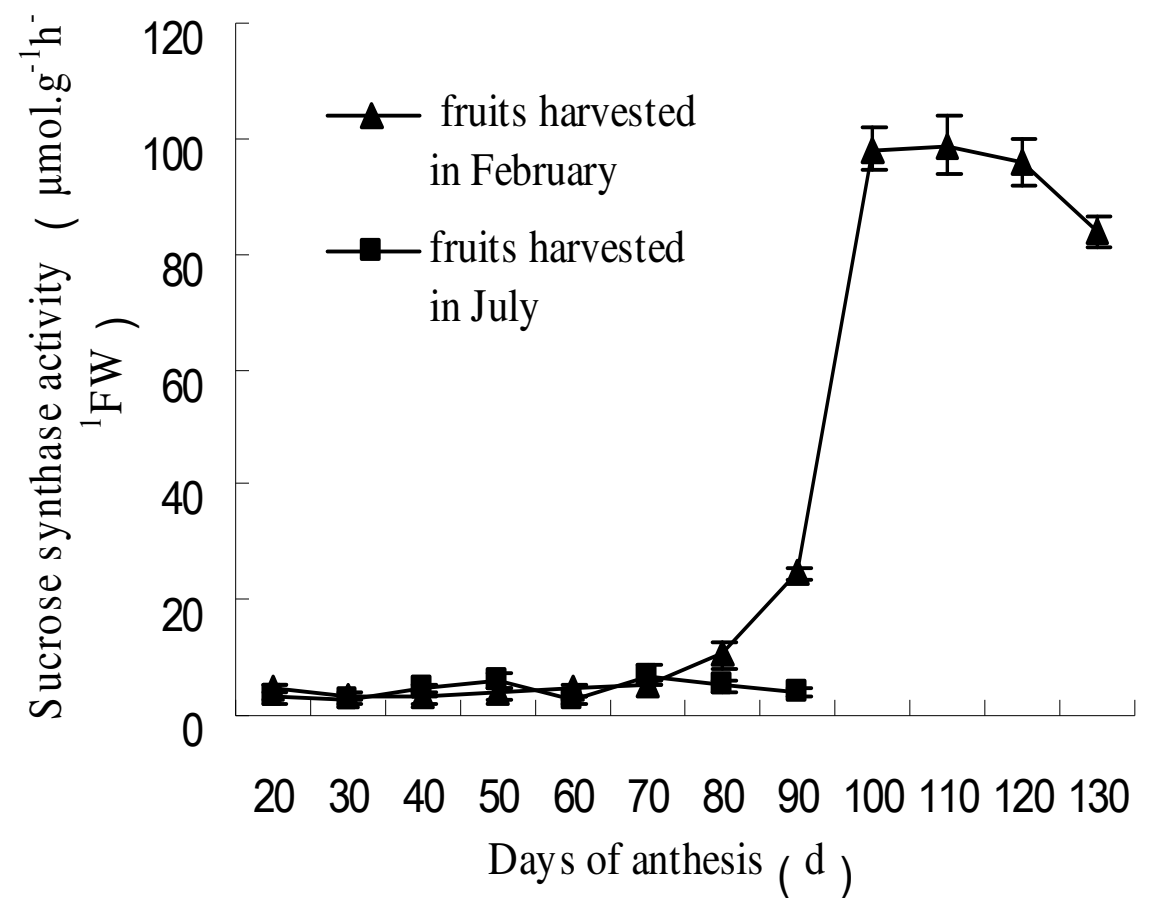

Figure 4. Effects of different harvest seasons on SS (synthesis) activities in the developing pineapple fruits.

than $5.0 \mu \mathrm{mol} \cdot \mathrm{g}^{-1} \mathrm{~h}^{-1} \mathrm{FW}$ until 60 days in both season fruits. However, it rapidly rose up from 4.45 to 98.16 $\mu \mathrm{mo} 1 \cdot \mathrm{h}^{-1} \mathrm{~g}^{-1} \mathrm{FW}$ with the range of 60 to 100 days (Figure 4). During mature stages, the SS activity of fruit harvested in winter, which increased continuously and reached the peak plateau from 100 to 120 days, declined slightly at the harvest. In summer fruit, the low value occurred on the whole development stages and fluctuated between 2.72 and $6.78 \mu \mathrm{mo} 1 \cdot \mathrm{h}^{-1} \mathrm{~g}^{-1} \mathrm{FW}$.

\section{The Al activity in different seasons}

The Al activity in the winter fruits generally rose up from 11.38 to $41.23 \mu \mathrm{mo} 1 \cdot \mathrm{h}^{-1} \mathrm{~g}^{-1} \mathrm{FW}$ during 20 to 40 days after anthesis, then decreased rapidly to the level of 4.57 $\mu \mathrm{mol} \cdot \mathrm{g}^{-1} \mathrm{~h}^{-1} \mathrm{FW}$ at the harvest (Figure 5). The changes were opposite to that of sucrose. In the summer fruits, the activity showed a slight fluctuation in the first growth period, sharply went up from the 40 to 70 days and finally dropped off after the 70 days. Its activity changes ranged from 8.2 to $31.72 \mu \mathrm{mol} \cdot \mathrm{g}^{-1} \mathrm{~h}^{-1} \mathrm{FW}$ in the stage of fruit development. Though the downward trend of Al activity was consistent between the different seasons, the total activity of the summer fruits was higher.

\section{The $\mathrm{Nl}$ activity in different seasons}

The $\mathrm{NI}$ activity was basically similar with $\mathrm{Al}$ activity in the winter fruits (Figure 6). In the winter fruits, the activity remarkably improved from 34.13 to $68.04 \mu \mathrm{mol} \cdot \mathrm{g}^{-1} \mathrm{~h}^{-1} \mathrm{FW}$, then dropped off to $16.21 \mu \mathrm{mol} \cdot \mathrm{g}^{-1} \mathrm{~h}^{-1} \mathrm{FW}$ at the harvest. In the summer fruits, the activity was lowered to 14.5 $\mu \mathrm{mol} \cdot \mathrm{g}^{-1} \mathrm{~h}^{-1} \mathrm{FW}$ before the beginning of development (from the 20 to 30 days), then rose up significantly from the 40 to the 70 days at the peak of $60.41 \mu \mathrm{mol} \cdot \mathrm{g}^{-1} \mathrm{~h}^{-1} \mathrm{FW}$, followed by a little drop (down 13\%) at the 80 days, and finally backed up. The activity in the summer ripen fruit was 3.63 times as high as that in the winter fruit.

\section{DISCUSSION}

In this study, a typical single ' $S$ ' curve (slow- fast- slow) was revealed during the whole development of the summer fruit, whereas the winter fruit was gentle from fast to slow. Moreover, the development period of the winter fruit was 40 days longer than that of the winter fruit (Paull and Rohrbach, 2002). We thought that those were maybe due to environmental factors, especially temperature, heavy rainfall and strong light in summer leading to the different tendency of sugar accumulation, which suggested that different harvest seasons had serious influence on the growth and size of fruit in the different stages of fruit development. Chen et al. (2007) suggested that the development period of the strawberry harvested in February was shorter than in January by 17 days, which was also consistent with our results. However, Cruz-Castillo et al. (1991) reported that the different flowering time had no 


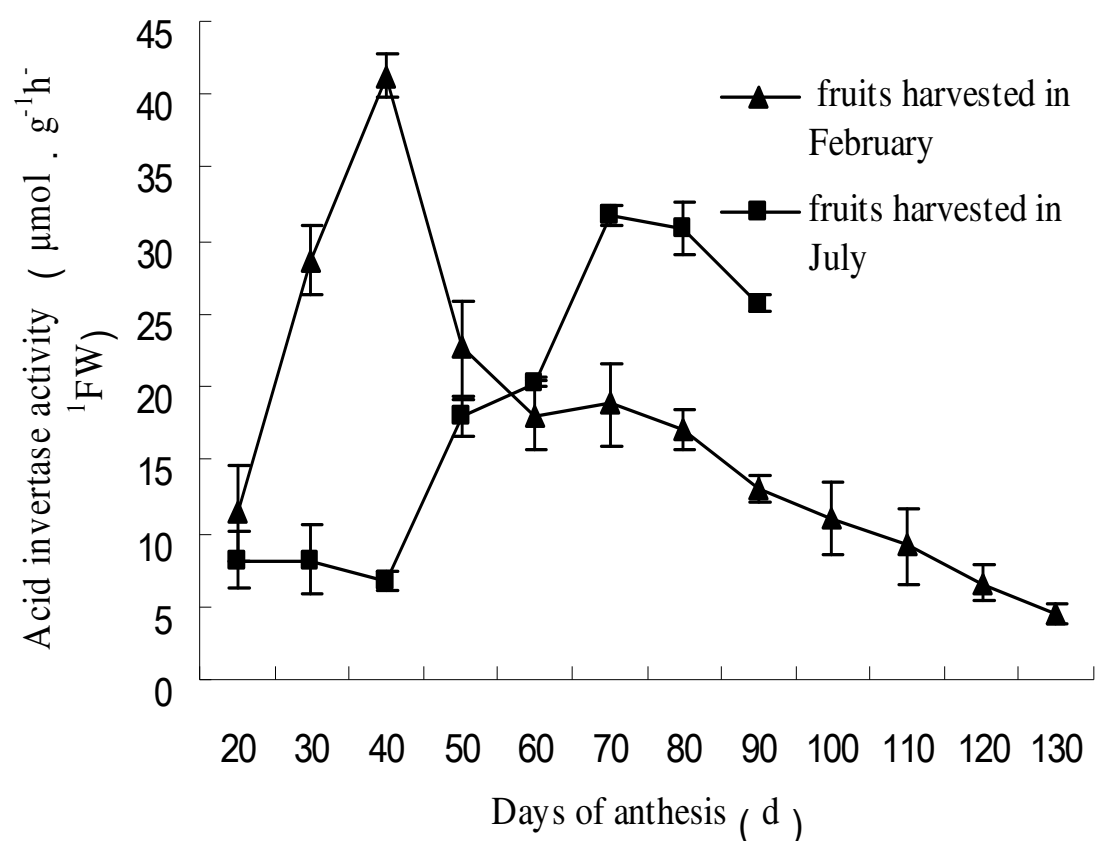

Figure 5. Effects of different harvest seasons on Al activities in the developing pineapple fruits.

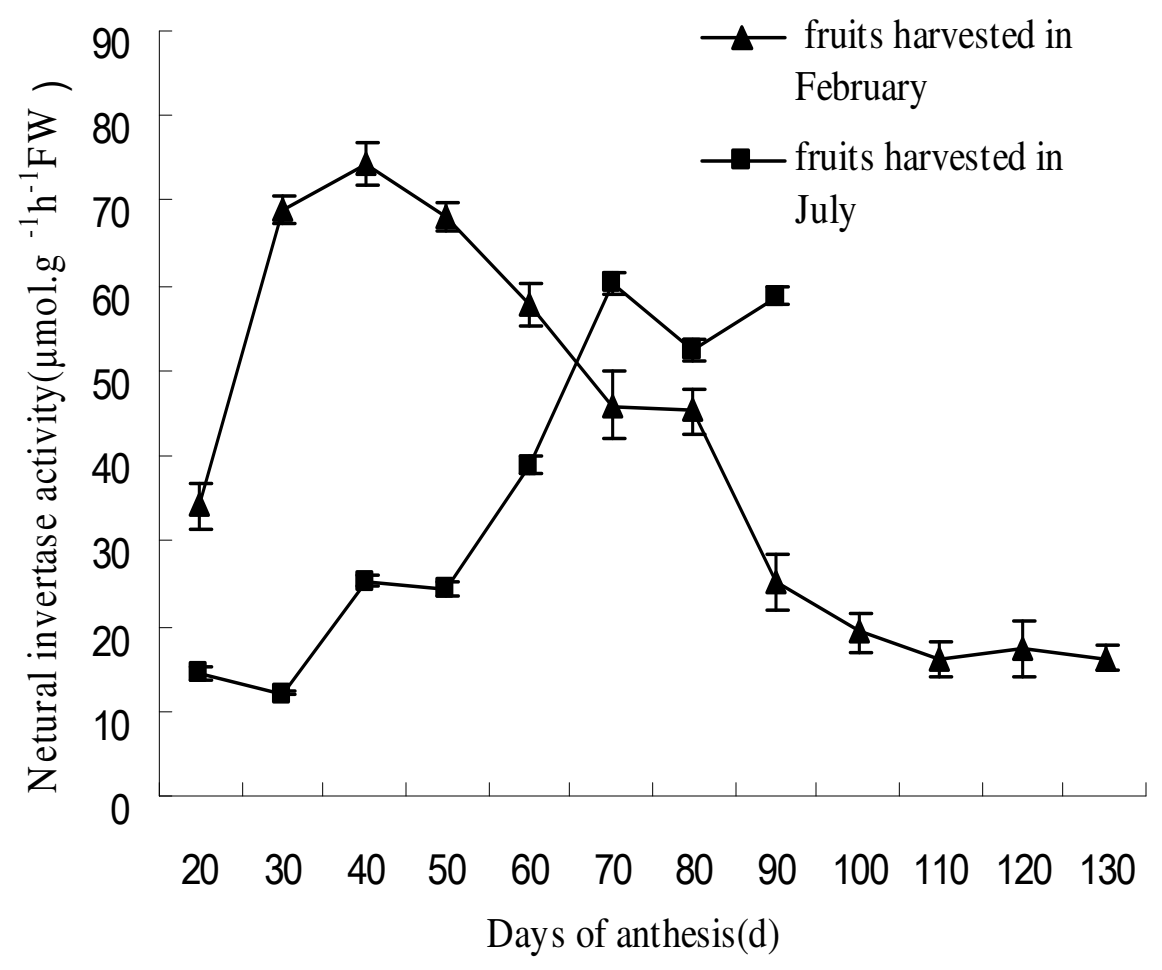

Figure 6. Effects of different harvest seasons on $\mathrm{NI}$ activities in the developing pineapple fruits.

influence on the kiwifruit's double ' $S$ ' growth and its fruit development. It indicated that different fruit had their own growth characteristic, though environmental factors such as water, temperature and light also had effect on fruit 
development (Léchaudel and Joas, 2007).

Sucrose, glucose and fructose are the main soluble carbohydrates. The content and the ratio of those elements played a vital role in deciding the flavor and quality of fruits. A large reports suggested that temperature is one of central factors involved in promoting the accumulation of sucrose in potatoes (Kumar et al., 2004), other vegetables (Bhowmik et al., 2001) and strawberry (Chen et al., 2007). However, in the present study, the sucrose content mainly accumulated in the winter fruit, and the sucrose metabolism enzyme activity may be affected by the different climatic conditions and inherent physiological characteristics.

The capability of sugar accumulation in the fruit was determined by the fruit sink strength, in which the activity of sucrose metabolism enzymes was an important physiological index. The enzymes that regulated sugar accumulation and metabolism in grape berry included AIV, SS and SPS (Copeland, 1990). Our experiment showed that a low invertase level and the high sucrose content appeared in the fruit early development, then the content of glucose and fructose was increased by the promotion of invertase activity. The change rule was similar with the result of peach (Moriguchi et al., 1990), kiwifruit (Macrae et al., 1992), and strawberry (Xie et al., 2007). The invertase activity was low in the early 70 day after anthesis in the summer fruit, which was beneficial for the accumulation of sucrose. But the Al activity declined in the late development, which was a typical characteristic of the sucrose accumulation fruit and consistent with golden pear ( $\mathrm{Li}$ et al., 2007), strawberry (Hubbard et al, 1991) and myrica rubra (Xie et al., 2005).

At maturity, the high activity of SPS and SS was a main reason of the winter fruit sucrose accumulation. In general, SPS activity had a high activity during plant maturation, which correlated with an enhanced accumulation of sugars in the root during its maturation (Pavlinova et al., 2002). Differences of SPS in winter and summer, may lead to the accumulation of sugars. In winter, pineapple had a long growth stage, so can accumulate more sugar than that in summer. Meanwhile, the changes of activity of SS were similar with SPS (Egger and Hampp, 1993).

Sugar is an important factor of fruit quality. Its content was determined by interaction between the gene, the natural environment and cultivation measures. The sugar accumulation was decided by the activity change of sucrose synthase and decompositase. Our research suggested that cultivation could change the composition of sugar in pineapple fruit, and this was done by the influence on the enzymes related to sucrose metabolism. The molecular regulation metabolism and how the external factors worked on those enzymes need further research.

\section{ACKNOWLEDGEMENTS}

Financial support was provided by the Guangdong Natural
Science Fund of China,the Hainan Natural Science Fund of China(808182), Special Fund for Agro-scientific Research in the Public Interest(3-41) , Fund on Basic Scientific Research Project of Nonprofit Central Research Institutions(200701).

\section{REFERENCES}

Bartolomé AP, Rupérez P, Fúster C (1996). Changes in soluble sugars of two pineapple fruit cultivars during frozen storage. Food Chem. 56(2): 163-166.

Bhowmik PK, Matsui T, Suzuki H,Kosugi Y,Enriquez FG, Alam A, Shameem KM (2001). Changes in carbohydrate content and the activities of acid invertase, sucrose synthase and sucrose phosphate synthase in Asparagus Spears during storage. Pak. J. Biol. Sci. 4(1): 94-97.

Chen C, Paull RE (1998). Changes in sugar content and activities of sugar metabolizing enzymes in pineapple fruit flesh during development. ISHS Acta Horticulturae 529: III International Pineapple Symposium.

Chen JW, Qin QP, Xie M, Jiang GH, Xu HX, Chen JH, Wu J, Sun CB (2007). Characteristics of sucrose and hexose metabolism in relation to sugar accumulation in developing strawberry fruit. J. Fruit Sci. 24(1): 49-54.

Colaric M, Stampar F, Ha M (2004). Contents of sugars and organic acids in the cultivars of peach (Prunus persica L.) and nectarine (Prunus persica var. nucipersica Schneid.). Acta Agric Slovenica. 83(1): 53-61.

Copeland L (1990). Enzymes of sucrose metabolism. In: Lea, P.J. (Ed.), Methods in Plant Biochemistry, vol. 3. Enzymes of Primary Metabolism. Academic Press, London, pp. 73-85.

Cruz-castillo JG, Lawes GS, Woolley DJ (1991). The influence of the time of anthesis, seed factors and the application of a growth regulator mixture on the growth of kiwifruit. Acta Hortic. 297: 475- 480.

D'Aoust MA, Yelle S, Nguyen-Quoc B (1999). Antisense inhibition of tomato fruit sucrose synthase decreases fruit setting and the sucrose unloading capacity of young fruit. Plant Cell. 11: 2407-2418.

Davies C, Robinson SP (1996). Sugar accumulation in grape berries. Cloning of two putative vacuolar invertase cDNAs and their expression in grapevine tissues. Plant Physiol. 111(1): 275-283.

De Bruyn JW (1971). Variation in taste and chemical composition of the tomato (Lycopersicon esculentum Mill.). Euphytica, 20: 214-227.

Eduardo P, Franco ML, Joao RO Beatriz RC (2001). Inhibition of $\beta$ amylase activity, starch degradation and sucrose formation by indole-3acetic during banana ripening. Planta, 212: 823-828.

Egger B, Hampp R (1993). Invertase, sucrose synthase and sucrose phosphate synthase in lyophilized spruce needles; microplate reader assays. Trees, 7: 98-103.

Gomez M, Lajolo F, Cordenunsi B (2002). Evolution of soluble sugars during ripening of papaya fruit and its relation to sweet taste. J. Food Sci. 67(1): 442-447.

Hubbard NL, Pharr DM, Huber SC (1991). Sucrose phosphate synthase and other sucrose metabolizing enzymes in fruits of various species. Physiol. Plant, 82: 191-196.

Itai A, Tanahashi T (2008). Inhibition of sucrose loss during cold storage in Japanese pear (Pyrus pyrifolia Nakai) by 1-MCP. Postharvest Biol. Technol. 48: 355-363.

Joomwong A (2006). Impact of cropping season in Northern Thailand on the quality of Smooth Cayenne pineapple. II. Influence on physicochemical attributes. Int. J. Agric. Biol. 8(3): 330-336.

Kermasha S, Barthakur NN, Alli I, Mohan NK (1987). Changes in chemical composition of the Kew cultives of pineapple, fruit during development. J. Sci. Food Agric. 39: 317-324.

Kumar D, Singh BP, Kumar P (2004). An overview of the factors affecting sugar content of potatoes. Ann. Appl. Biol. 145: 247-256.

Léchaudel M, Joas J (2007). An overview of preharvest factors influencing mango fruit growth, quality and postharvest behavior. Brazilian J. Plant Physiol. 19(4): 287-298.

Li YM, Wang XT, Wang YZ, Liu GS (2007). Effects of bagging on sugar 
metabolism and related enzyme activities in whangkeumbase pear. Northern Horticulture, 7:43-46.

Macrae E, Quick WP, Benker C, Zhang GP, Zhong Y, Jiang B, Luo MH (1992). Carbohydrate metabolism during postharvest ripening in kiwifruit. Planta, 188: 314-323.

Moriguchi T, Sanada T, Yamaki S (1990). Seasonal fluctuation of some enzymes relating to sucrose and sorbitol metabolism in peach fruit. $\mathrm{J}$ Am. Soc. Hortic. Sci. 115: 278-281.

Moriguchi T, Abe K, Sanada T, Yamaki S (1992). Levels and role of sucrose synthase, sucrose-phosphate synthase, and acid invertase in sucrose accumulation in fruit of Asian pear. J. Am. Soc. Hortic. Sci. 117(2): 274-278.

Miron D, Schaffer AA (1991). Sucrose phosphate synthase sucrose synthase, and invertase activities in developing fruit of lycopersicon esculentum mill. and the sucrose accumulating lycopersicon hirsutum humb. and bonpl. Plant Physiol, 95(2): 623-627.

Nilprapruck P, Pradisthakarn N, Authanithee F and Keebjan P (2008). Effect of Exogenous Methyl Jasmonate on Chilling Injury and Quality of Pineapple (Ananas comosus L.) cv. Pattavia. Silpakorn Univ. Sci. Tech. J. 2(2): 33-42.

N'tchobo H, Dali N, Nguyen-Quoc B, Foyer CH, Yelle S (1999). Starch synthesis in tomato remains constant throughout fruit development and is dependent on sucrose supply and sucrose synthase activity. J. Exp. Bot. 50: 1457-1463.

Park JY, Canam T, Kang KY, Unda F, Mansfield S(2009).Sucrose phosphate synthase expression influences poplar phenology.Tree Physiol. 29(7):937-946.

Paull RE, Rohrbach KG (2002). The pineapple botany, production and uses. Hawaii: $\mathrm{CABI}$ p36 publishing.

Qi XP, Wu ZC, Li JH, Mo XR, Wu SH, Chu J, Wu P (2007).AtCYTINV1, a netural invertase, is involved in osmotic stress-induced inhibition on lateral root growth in Arabidopsis.Plant Mol.Biol.64:575587.
Róth E, Bernaa A, Beullens K, Yarramraju S, Lammertyn J, Schenk A, Nicolaï B (2007). Postharvest quality of integrated and organically produced apple fruit. Postharvest Biol. Technol. 45(1): 11-19.

Shinjro S, Kumi C, Reinosuke N (2004). Postharvest ripening of pineapple fruits in terms of changes in some chemical constituents. Food Preserv. Sci. 30 (5): 231-234.

Tanase K, Yamaki S (2000). Purification and Characterization of Two Sucrose Synthase Isoforms from Japanese Pear Fruit. Plant Cell Physiol. 41: 408-414.

Veberic R, Zadravec P, Stampar F (2007). Fruit quality of 'Fuji' apple (Malus domestica Borkh.) strains. J. Sci. Food Agric. 87(4): 593-599.

Xie M, Chen JW, Chen JH, Qing QP, Jiang GH, Wang LH, Wang YB, Qi XJ (2005). Studies on the fruit development and its relationship with sugar accumulation in bayberry fruit. J. Fruit Sci. 22(6): 634-638. (in Chinese).

Xie M, Chen JW, Qin QP, Jiang GH, Sun CB, Zhang HQ, Xu HX (2007). The control of sugar accumulation within strawberry aggregate fruit by invertase and hexokinase. J. Plant Physiol. Mol. Biol. 33(3): 213-218.

Yamaki S, Moriguchi T (1989). Seasonal fluctuation of sorbitol-related enzymes and invertase activities accompanying maturation of Japanese pear (Pyrus serotina Rehder var. culta Rehder). J. Jpn. Soc. Hort. Sci. 57(4): 602-607. 